\title{
DOES NICKEL INFLUENCE LEAF NITROGEN UPTAKE IN COFFEE SEEDLINGS?
}

\author{
Isabeli Pereira Bruno ${ }^{1}$, Milton Ferreira Moraes ${ }^{2}$, Virgínia Damin ${ }^{3}$, Durval Dourado-Neto ${ }^{4}$, \\ Klaus Reichardt ${ }^{5}$
}

${ }^{1}$ Agronomic Institute of Paraná - IAPAR. E-mail: isabelibruno@gmail.com

${ }^{2}$ Federal University of Mato Grosso - UFMT. E-mail: moraesmf@ yahoo.com.br

${ }^{3}$ Federal University of Goiás - UFG. E-mail: virginiadamin@ gmail.com

${ }^{4}$ University of São Paulo - ESALQ/USP. E-mail: d.dourado.n@gmail.com

${ }^{5}$ University of São Paulo - CENA-ESALQ/USP. E-mail: nikolaus.rei@gmail.com

\section{ABSTRACT}

Nickel is an essential element in plants, mainly acting as a component of the urease enzyme. Therefore, its use in foliar solutions could increase nitrogen use efficiency. This work aimed to evaluate leaf nitrogen absorption in coffee seedlings (1-year-old), using two nitrogen application rates with nickel presence or absence, during 24 hours. The results showed, however, that nickel addition to the leaf solution impairs the absorption of nitrogen, at least on the first day after application.

Keywords: Isotope, ${ }^{15} \mathrm{~N}$, nutrient use efficiency, Coffea arabica

\section{O NÍQUEL INFLUENCIA A ABSORÇÃO FOLIAR DE NITROGÊNIO EM MUDAS DE CAFEEIRO?}

\section{RESUMO}

O níquel é um elemento essencial para as plantas, atuando principalmente como componente da enzima urease. Portanto, o seu uso em soluções foliares poderia aumentar a eficiência do uso de nitrogênio. O objetivo deste trabalho foi avaliar a absorção de nitrogênio foliar em mudas de cafeeiros (1 ano de idade), utilizando duas doses de aplicação de nitrogênio com presença ou ausência de níquel, durante 24 horas. Os resultados mostraram, no entanto, que a adição de níquel à solução foliar prejudica a absorção de nitrogênio, pelo menos no primeiro dia após a aplicação.

Palavras-chave: Isótopo, ${ }^{15} \mathrm{~N}$, eficiência do uso de nutrientes, Coffea arabica 


\section{INTRODUCTION}

Nitrogen $(\mathrm{N})$ is one of the nutrients most required by plants and the agricultural crops. They obtain this element from several sources; from the soil as $\mathrm{NO}_{3}{ }^{-}$or $\mathrm{NH}_{4}{ }^{+}$, via mineral fertilization and fixation from the atmosphere. Among the fertilizers, the urea is widely used in nitrogen fertilization because of its relatively low cost, easy management and high $\mathrm{N}$ concentration (45$46 \%$ ). Besides these advantages, urea also has high solubility and fast absorption through the foliage, which makes foliar spraying and fertigation via pivot very useful. Recent reviews on the principles of leaf fertilization can be found in Fernández \& Brown (2013), Haytova (2013) and Singh et al. (2013).

Nutrient foliar absorption begins with the nutrient contact with the upper, lower or both epidermis, and may or not have absorption energy expenditure depending on the step of the process. Countless factors influence leaf absorption, such as plant species or type of the solution applied. Absorption of nutrients also occurs via stomata, which concentrate on the coffee mainly on the abaxial side of the leaf (MALAVOLTA, 2006).

As far as urea absorption is concerned, there are at least three enzymes involved in its metabolism in plants: arginase, glutamine synthetase and urease. Urease is a nickel (Ni) dependent metal-enzyme, which catalyzes the hydrolysis of urea into ammonia $\left(\mathrm{NH}_{3}\right)$ and carbon dioxide $\left(\mathrm{CO}_{2}\right)$. The main role of urease is to allow organisms to use internally or externally generated urea as $\mathrm{N}$ source, which will not be available to plants unless hydrolysis has occurred. After urease action, $\mathrm{N}$ is quickly metabolized and incorporated into amino acids and amides. The urease foliar activity is very important when $\mathrm{N}$ comes from foliar applications, and although this enzyme helps in the efficient $\mathrm{N}$ assimilation, ammonia toxicity can occur when its activity is too high (BARCELOS et al., 2018; BARCELOS et al., 2017; BOER et al., 2014; POLACCO et al., 2013).

Several studies confirm the influence of $\mathrm{Ni}$ on $\mathrm{N}$ uptake, such as the study with rice plants, carried out by Gerendas et al. (1998). In their work, plants presented reduced growth and large amounts of accumulated urea due to the reduction of urease activity. Similar results were obtained previously by Walker et al. (1985), Krogmeier et al. (1991) and more recently by Moraes et al. (2009), Barcelos et al. (2018), and Freitas et al. (2018). Therefore, the addition of Ni in solutions of urea for spraying or fertigation could also increase the $\mathrm{N}$ fertilizer use efficiency and maximize the profits of farmers. 
The coffee crop is one of the main products exported by Brazil and its cultivation has been intensified in new coffee production areas like those of the cerrado in the State of Bahia, Brazil, where large extensions of monoculture are cultivated under central pivot technology using fertigation. Although the uptake of $\mathrm{N}$ via foliar by coffee trees has already been proven (MENDES et al., 1961; MALAVOLTA, 2006), the role of $\mathrm{Ni}$ in this process is controversial. These controversies concern the proportion of $\mathrm{N}$ absorbed by the soil and leaves, the increase in $\mathrm{N}$ uptake when $\mathrm{Ni}$ is added to the urea solution and the $\mathrm{N}$ uptake in coffee trees of different ages.

Looking for responses to the doubts stated above, the present work aimed to evaluate the leaf $\mathrm{N}$ uptake from an urea solution, in coffee seedlings fertilized with two different $\mathrm{N}$ rates, in the presence or absence of $\mathrm{Ni}$, during 24 hours.

\section{MATERIAL AND METHODS}

The experiment was carried out in a greenhouse (Piracicaba, SP, Brazil, 22.7084 $\mathrm{S}$, $47.6438^{\circ} \mathrm{W}$ ), using plastic pots containing $10 \mathrm{~kg}$ of soil (Oxisol) with corrected $\mathrm{pH}$ and previously fertilized with non-nitrogen sources of phosphorus and potassium. The one-year old coffee seedlings were transplanted (one plant per pot) and after 30 days the fertilizer solution of the treatments was applied. The fertilizers used were urea enriched in $1.035 \%{ }^{15} \mathrm{~N}$, with $\mathrm{N}$ concentration of $45 \%$. In the treatment with $\mathrm{Ni}$, the element addition was made with nickel sulfate $\left(\mathrm{NiSO}_{4} \cdot 6 \mathrm{H}_{2} \mathrm{O}\right)$, $22 \% \mathrm{Ni}$. The treatments used the rates of 31 and $16 \mathrm{mg} \mathrm{N} \mathrm{N}$ plant $^{-1}$, corresponding to 50 and $25 \mathrm{~kg}$ $\mathrm{N} \mathrm{ha}^{-1}$ (Table 1). Treatments with $\mathrm{Ni}$ addition received $0.05 \mathrm{mg}$ of $\mathrm{Ni}^{\text {plant }}{ }^{-1}$, corresponding to 80 $\mathrm{g} \mathrm{Ni} \mathrm{ha}{ }^{-1}$ added to the urea solution. The experimental design was completely randomized, with five treatments (control, two $\mathrm{N}$ rates, and presence or absence of $\mathrm{Ni}$ ), in four replicates (Table 1).

Table 1. Characterization of treatments and respective rates of nitrogen $(\mathrm{N})$ and nickel $(\mathrm{Ni})$, in May 2009, Piracicaba, São Paulo State, Brazil.

\begin{tabular}{|c|c|c|}
\hline Treatment & N Rate (mg plant ${ }^{-1}$ ) & Ni Rate (mg plant $\left.{ }^{-1}\right)$ \\
\hline $\mathrm{T}_{0}$ & 0 & 0.00 \\
\hline $\mathrm{T}_{16}$ & 16 & 0.00 \\
\hline $\mathrm{T}_{16 \mathrm{Ni}}$ & 16 & 0.05 \\
\hline $\mathrm{T}_{31}$ & 31 & 0.00 \\
\hline $\mathrm{T}_{31 \mathrm{Ni}}$ & 31 & 0.05 \\
\hline
\end{tabular}


The urea solution had the concentration of $2.5 \%$, and the respective treatments were applied early in the morning to the upper surface of all the leaves of the seedlings using a pipette and avoiding any loss to the soil.

Four seedlings of each treatment were harvested after 1,2, 12, and 24 hours after fertilizer application. Plants were separated into leaves, stems and roots, washed in distilled water and dried in a ventilated oven at $60^{\circ} \mathrm{C}$ until constant weight. The dry mass of each plant part was evaluated and the samples were then milled in a Wiley-type mill. After milling, a sample aliquot of the different plant parts was weighed separately to determine total $\mathrm{N}$ and ${ }^{15} \mathrm{~N}$ enrichment in a mass spectrometer model ANCA-SL, 20-20 of PDZ Europe, Krewe, UK, at the Stable Isotope Laboratory of University of Sao Paulo - Center for Nuclear Energy - CENA / USP, in Piracicaba, São Paulo state, Brazil.

With results of total $\mathrm{N}(\mathrm{Nt})$ and ${ }^{15} \mathrm{~N}$ enrichment the following calculations were performed for the different organs (leaves, stems and roots).

The percentage of $\mathrm{N}$ in the sample derived from fertilizer (Ndff, \%):

$$
N d f f=\frac{\left({ }^{15} N \text { atom } \% \text { excess }\right) \text { organ }}{\left({ }^{15} N \text { atom } \% \text { excess }\right) \text { fertilizer }} .100
$$

The amount of $\mathrm{N}$ in the organ derived from fertilizer in the different plant parts (QNdff, $\left.\operatorname{mg} \operatorname{organ}^{-1}\right)$ :

$$
Q N d f f=\frac{N d f f \cdot N t}{100}
$$

The nitrogen fertilizer efficiency $(\mathrm{E}, \%)$ for different plant parts:

$$
E=\frac{Q N d f f}{Q N A} .100
$$

Where QNA is the amount of $\mathrm{N}$ applied per plant $\left(\mathrm{mg} \mathrm{plant}^{-1}\right)$.

The variance analysis with repeated evaluations in time and Tukey test (level of 5\% probability) was performed for Ndff, QNdff and E, using the Statistica software, 8.0 (STATSOFT, 2007). 


\section{RESULTS AND DISCUSSION}

Stem and root did not present ${ }^{15} \mathrm{~N}$ enrichment, only natural abundance (average of $0.365 \%$ of ${ }^{15} \mathrm{~N}$ atoms) for all treatments and all collections made up to 24 hours after the foliar application.

Regarding leaves, their total $\mathrm{N}$ was on average $34 \mathrm{~g} \mathrm{~kg}^{-1}$ and did not show significant difference between the treatments or between the hours after application.

There was no difference between the first and second hours after foliar fertilization for Ndff, QNdff and E. However, these same variables had increasing values after 12 and 24 hours for all treatments except T16, whose values decreased in the last evaluation (Figures 1, 2 and 3).

Figure 1 shows the Ndff evolution in the coffee seedling leaves. The percentage of Ndff is directly proportional to the rate of applied N, with $\mathrm{T} 31$ and T31Ni being superior to the others and not differing from each other. The lower rate, on the other hand, was significantly different between treatments with and without $\mathrm{Ni}$, and the last one was superior. Approximately $11 \%$ and $7 \%$ of the $\mathrm{N}$ found in the coffee seedling leaves came from the fertilizer after 24 hours from application, for treatments $\mathrm{T} 31$ and $\mathrm{T} 31 \mathrm{Ni}$, respectively.

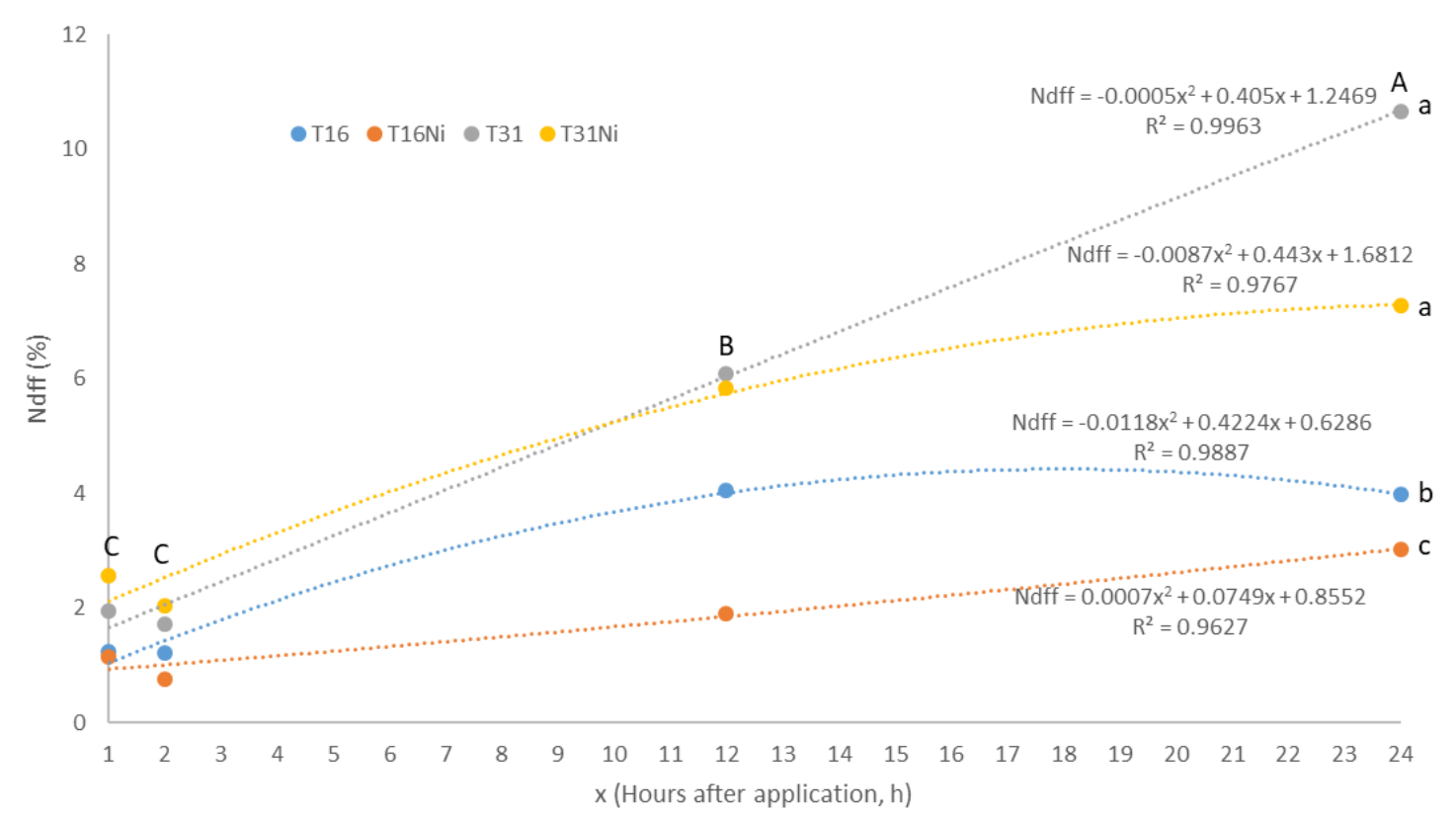

Figure 1. Evolution of nitrogen derived from fertilizer (Ndff, \%) in coffee seedlings after the application of different doses of nitrogen $(\mathrm{N})$ in the absence or presence of nickel (Ni). $\mathrm{T}_{0}=$ control treatment without $\mathrm{N}$ and without $\mathrm{Ni} ; \mathrm{T}_{16}=$ dose of $16 \mathrm{mg} \mathrm{N}$ plant $^{-1}$ and $0 \mathrm{mg} \mathrm{Ni}$ plant ${ }^{-1} ; \mathrm{T}_{16 \mathrm{Ni}}$ $=$ dose of $16 \mathrm{mg} \mathrm{N}_{\text {plant }}^{-1}$ and $0.05 \mathrm{mg}[\mathrm{Ni}]$ plant $^{-1} ; \mathrm{T}_{31}=$ dose of $31 \mathrm{mg} \mathrm{N}$ plant $^{-1}$ and $0 \mathrm{mg} \mathrm{Ni}$ plant $^{-1}$; $\mathrm{T}_{31 \mathrm{Ni}}=$ dose of $31 \mathrm{mg} \mathrm{N}$ plant $^{-1}$ and $0,05 \mathrm{mg} \mathrm{Ni}$ plant ${ }^{-1}$. Capital letters refer to hours after application. Lowercase letters refer to treatments. Equal letters do not differ by Tukey's test $(\mathrm{P}>0.05)$. 
The QNdff follows the Ndff curves and likewise, the higher the rate of applied $\mathrm{N}$ via the leaf, the greater the amount of $\mathrm{N}$ from the fertilizer in the leaves (Figure 2). There is significant difference between treatments with and without $\mathrm{Ni}$ for higher rate, and it is interesting to observe that in the first hour the treatments with Ni presented higher QNdff than the treatments without Ni, with an inversion from 12 hours after application.

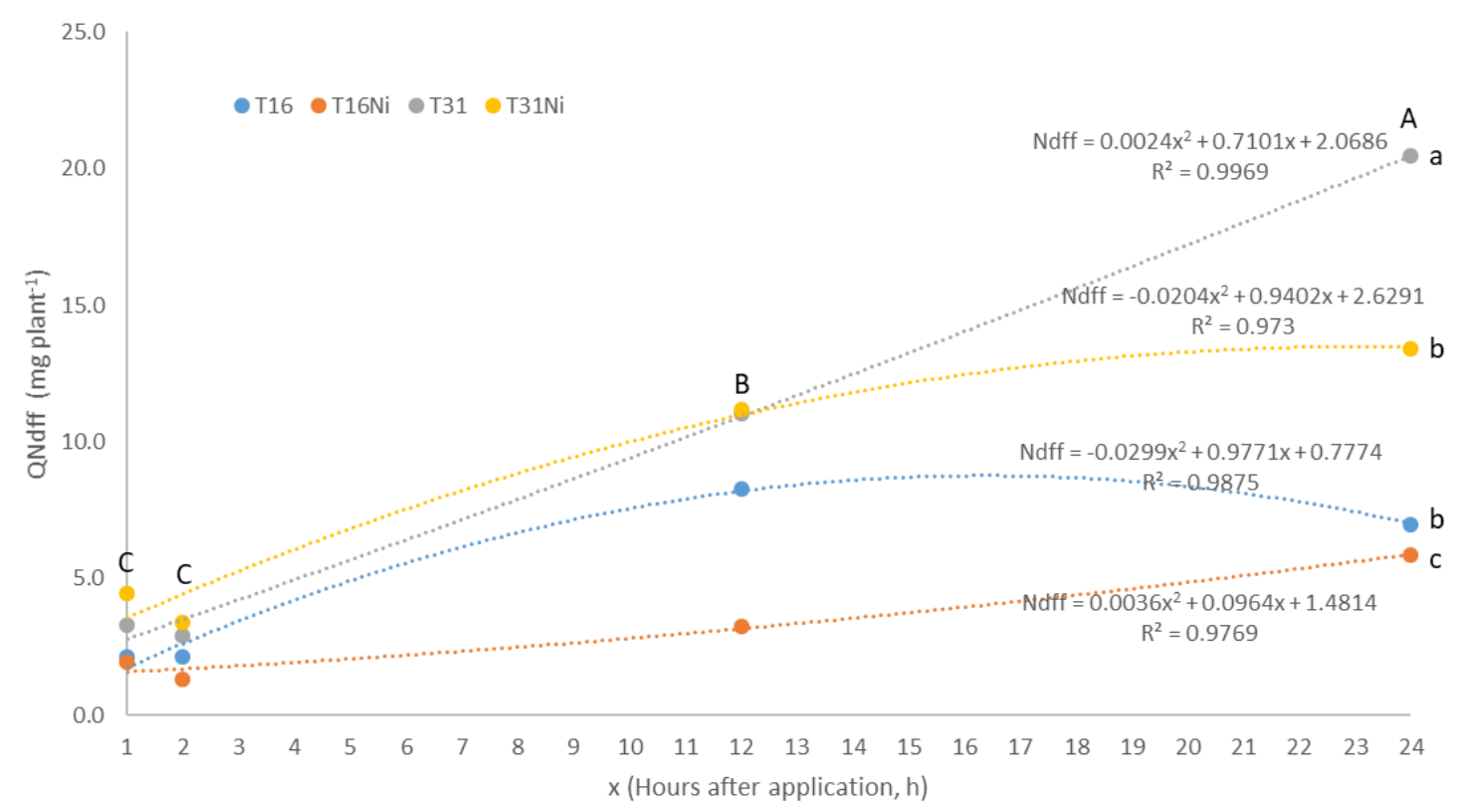

Figure 2. Evolution of the amount of nitrogen derived from fertilizer (QNdff) $\left(\mathrm{mg} \mathrm{leaves}^{-1}\right)$ in coffee seedlings, after the application of different nitrogen $(\mathrm{N})$ doses, in the absence or presence of nickel $(\mathrm{Ni})$.

$\mathrm{T}_{0}=$ control treatment without $\mathrm{N}$ and without $\mathrm{Ni} ; \mathrm{T}_{16}=$ dose of $16 \mathrm{mg} \mathrm{N}$ plant $^{-1}$ and $0 \mathrm{mg} \mathrm{Ni}$ plant $^{-1} ; \mathrm{T}_{16 \mathrm{Ni}}$

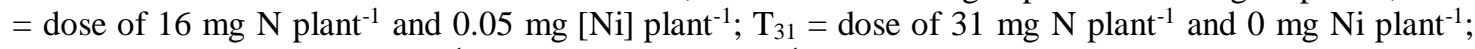
$\mathrm{T}_{31 \mathrm{Ni}}=$ dose of $31 \mathrm{mg} \mathrm{N}$ plant $^{-1}$ and $0,05 \mathrm{mg} \mathrm{Ni}$ plant $^{-1}$. Capital letters refer to hours after application. Lowercase letters refer to treatments. Equal letters do not differ by Tukey's test $(\mathrm{P}>0.05)$.

Figure 3 shows the efficiency, which represents the quantity of $\mathrm{N}$ from fertilizer per unit leaf mass. Although there is no significant difference in QNdff between treatments T16 and T31Ni, they also presented the same efficiency at the end of the experiment, and treatment with the lower $\mathrm{N}$ rate plus $\mathrm{Ni}$ differed significantly from the others, and was less efficient. 


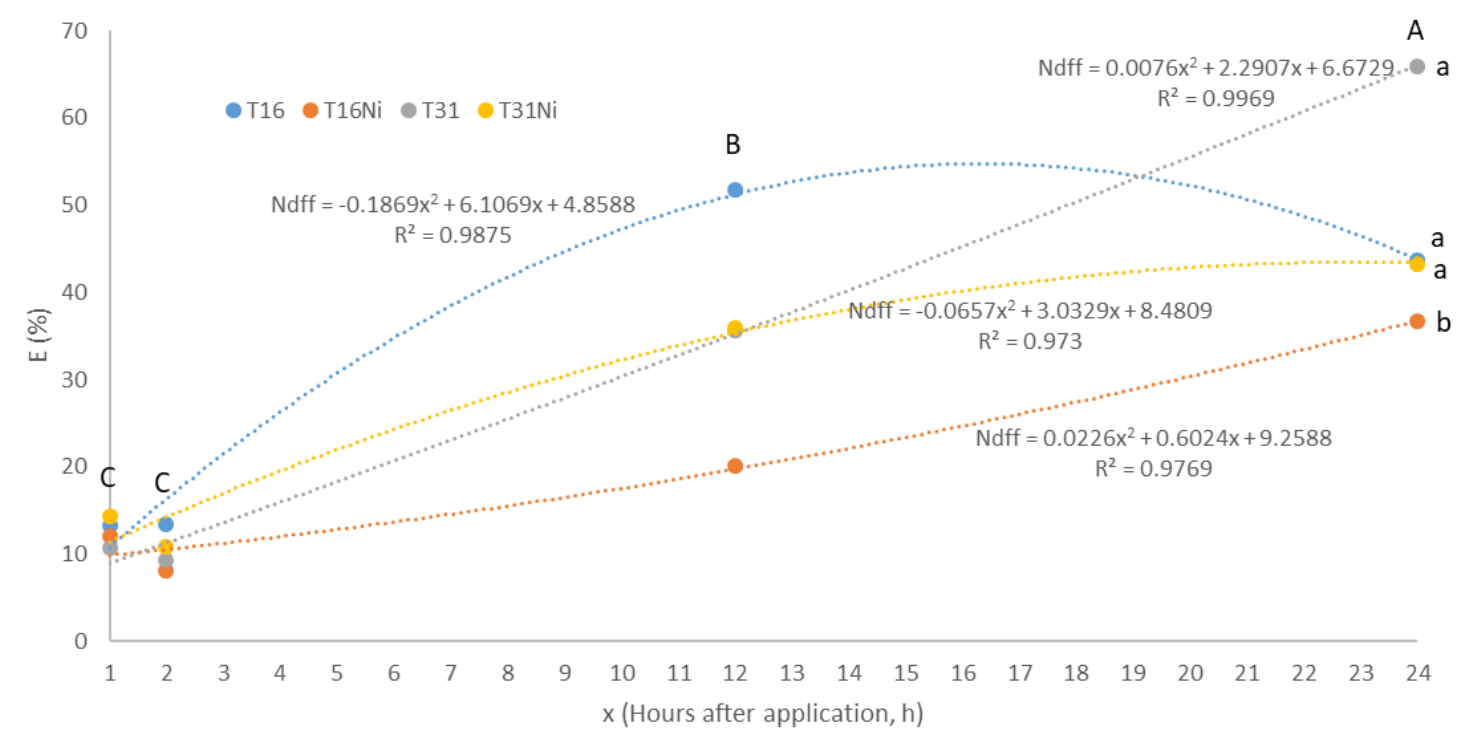

Figure 3. Efficiency (E) of nitrogen fertilizer $(\mathrm{N})$, applied at different doses in coffee seedlings in the presence or absence of nickel $(\mathrm{Ni})$.

$\mathrm{T}_{0}=$ control treatment without $\mathrm{N}$ and without $\mathrm{Ni} ; \mathrm{T}_{16}=$ dose of $16 \mathrm{mg} \mathrm{N}$ plant $^{-1}$ and $0 \mathrm{mg} \mathrm{Ni}$ plant ${ }^{-1} ; \mathrm{T}_{16 \mathrm{Ni}}$ $=$ dose of $16 \mathrm{mg} \mathrm{N}_{\text {plant }}{ }^{-1}$ and $0.05 \mathrm{mg} \mathrm{Ni}$ plant $^{-1} ; \mathrm{T}_{31}=$ dose of $31 \mathrm{mg} \mathrm{N}$ plant $^{-1}$ and $0 \mathrm{mg} \mathrm{Ni}$ plant ${ }^{-1} ; \mathrm{T}_{31 \mathrm{Ni}}$ $=$ dose of $31 \mathrm{mg} \mathrm{N}$ plant ${ }^{-1}$ and $0,05 \mathrm{mg} \mathrm{Ni}$ plant ${ }^{-1}$. Capital letters refer to hours after application. Lowercase letters refer to treatments. Letters are equal do not differ by Tukey's test $(\mathrm{P}>0.05)$.

The fact that stem and root presented natural ${ }^{15} \mathrm{~N}$ abundance shows that after 24 hours the $\mathrm{N}$ applied on the leaf, with or without the Ni presence, was not translocated to these plant parts, showing that the transport takes more than 24 hours. Another possibility is that $\mathrm{N}$ is stored in the leaves, to be later translocated directly to the production of new organs.

The results of rate of total $\mathrm{N}$ absorption are similar to those found by Boaretto et al. (1999) in orange tree seedlings that received leaf fertilization of ${ }^{15} \mathrm{~N}$ urea, where there was no significant difference on the $\mathrm{N}$ content after two days, although more than half of the $\mathrm{N}$ had already been absorbed. In the work of Klein \& Weinbaum (1985) with olive trees, the authors observed a $47 \%$ increase in $\mathrm{N}$ content only after 10 days after application and there was no difference between $\mathrm{N}$ rates with or without Ni. Janjanin et al. (2016) applying N-urea via leaf four times during grape harvest only observed an increase in leaf $\mathrm{N}$ concentration in the second year of the study.

Figures 1 and 2 show that in this experiment the presence of $\mathrm{Ni}$, besides having not favored the $\mathrm{N}$ foliar absorption, had a negative effect which was the decrease in $\mathrm{N}$ leaf uptake. This result contradicts other similar studies. In the work of Barcelos et al. (2017), foliar application of a Ni- 
single solution was made, and they observed a linear increase in leaf $\mathrm{N}$ concentration. Although the work of Freitas et al. (2018) having used Ni fertilization in soybean cultivated soil, there was also an increase in leaf $\mathrm{N}$ concentration, among other increases in $\mathrm{N}$ metabolism. Hosseini \& Khoshgoftarmanesh (2013) observed that the effectiveness of foliar application of urea-Ni in increasing fresh weight and improving $\mathrm{N}$ metabolism of lettuce was dependent on plant cultivar, highlighting the complexity of Ni-N interaction.

The percentage of Ndff after one day (3 to 11\%) (Figure 1) disagrees with some previous studies, but agrees with others. While some studies show that most Ndff has been absorbed within hours, other studies have shown that the same percentage can be reached only after several days. This discrepancy is probably due to various plant factors (e.g. wax layer on leaf), the environment, and the mode of application of the fertilizer solution that may influence $\mathrm{N}$ uptake rate via leaf, clearly shown by Bondada et al. (2001). In this study, the authors evaluated the absorption of ${ }^{15} \mathrm{~N}$ urea by citrus seedling leaves and found that the maximum absorption of ${ }^{15} \mathrm{~N}$-urea occurs between $20 \mathrm{~h}$ and $22 \mathrm{~h}$ after application, applied to the underside of young plant leaves exposed to sufficient $\mathrm{N}$ nutrition.

Regarding the absorption time, after 12 hours there was significant difference in Ndff absorbed via leaf, increasing up to 24 hours. Probably, the percentage of Ndff would increase if the experiment had been evaluated for a longer period, which leaves open the question of how long it takes coffee seedling leaves to absorb at least $50 \%$ of $\mathrm{N}$ applied via leaf. However, the present study demonstrated that this process is slow, similar to that observed by Bondada et al. (2001) in citrus seedlings, when the authors observed a decrease in $\mathrm{N}$ uptake with increasing leaf age, which was attributed to the accumulation of wax on the leaf surface over time, which is probably also the case for the coffee plant. Trivelin et al. (1988) pulverized ${ }^{15} \mathrm{~N}$-urea solution on sugarcane and found that more than $50 \%$ of the $\mathrm{N}$ was absorbed after 6 hours. In a study with Camellia sinensis seedlings performed by Ruan \& Gerendás (2015), it was shown that the ${ }^{15} \mathrm{~N}$ absorption rate was higher (8 to $16 \%$ ) in the first 6 hourss after application. In grasses, Stiegler et al. (2011) observed that up to $67 \%$ of leaf-applied ${ }^{15} \mathrm{~N}$ had been absorbed within the first hour after application. Dong et al. (2002) observed that $35 \%$ of $\mathrm{N}$ applied via leaf as a urea solution had been absorbed by apple leaves after 20 days. In orange plants, $52 \%$ of the applied $\mathrm{N}$ was absorbed in the first 48 hours (BOARETTO et al., 1999). 
In the first hour after application, the leaves under treatments with $\mathrm{Ni}$ application presented higher QNdff, and this may indicate that for coffee seedlings, the Ni favors the foliar $\mathrm{N}$ uptake at the beginning, but with time this stimulation disappears and starts to harm the foliar $\mathrm{N}$ absorption 24 hours after the application (Figure 2).

In Figure 3, the highlight was that only the T16Ni treatment differed significantly from the others, showing the lowest value and reinforcing the idea that the Ni presence impairs the $\mathrm{N}$ foliar absorption.

\section{CONCLUSION}

The addition of $\mathrm{Ni}$ in the urea solution impaired $\mathrm{N}$ uptake by coffee seedlings because when Ni was present in the solution, the leaf always absorbed less than when nickel was not present, unlike expected. Considering the essential role of $\mathrm{Ni}$ in the $\mathrm{N}$ metabolism in plants, particularly in the urease, longer-term studies must be performed to improve the understanding about this process in the coffee crop.

\section{ACKNOWLEDGEMENTS}

To Wesley Moreira, for practical support.

\section{REFERENCES}

BARCELOS, J. P. Q.; OSÓRIO, C. R. W. S.; LEAL, A. J. F.; ALVES, C. Z.; SANTOS, E. F.; REIS, H. P. G.; REIS, A. R., 2017. Effects of foliar nickel (Ni) application on mineral nutrition status, urease activity and physiological quality of soybean seeds. Australian Journal of Crop Science, Brisbane, v. 11, n. 2, p. 184-192. Available at: https://search.informit.com.au/documentSummary;dn=821675210304039;res=IELHSS, Access in: 23/08/19

BARCELOS, J. P. Q.; REIS, H. P. G.; GODOY, C. V.; GRATÃO, P. L.; FURLANI JR., E.; PUTTI, F. F.; CAMPOS, M.; REIS, A. R., 2018. Impact of foliar nickel application on urease activity, antioxidant metabolism and control of powdery mildew (Microsphaera diffusa) in soybean plants. Plant Pathology, Jersey City, v. 67, p. 1502-1513. Available at: https://onlinelibrary.wiley.com/doi/abs/10.1111/ppa.12871, Access in: 23/08/19

BOARETTO, A.E.; SCHIAVINATO-NETO, P.; MURAOKA, T.; OLIVEIRA, M.W.; TRIVELIN, P.C.O., 1999. Foliar nitrogen supply to young citrus plants. Scientia Agricola, Piracicaba, v. 56, p. 621-626. Available at: http://www.scielo.br/scielo.php?pid=S010390161999000300015\&script=sci_abstract, Access in: 10/08/19

BOER, J. L.; MULROONEY, S. B.; HAUSINGER, R. P., 2014. Nickel-dependent metalloenzymes. Archives of Biochemistry and Biophysics, New York, v. 544, p.142-152. Available 
https://www.sciencedirect.com/science/article/pii/S0003986113002713?via\%3Dihub, Access in: 09/08/19

BONDADA, B. R.; SYVERTSEN, J. P.; ALBRIGO, L. G., 2001. Urea nitrogen uptake by citrus leaves. Hortscience, Alexandria, v. 36, n.6, p. 1061-1065. Available at: https://journals.ashs.org/hortsci/view/journals/hortsci/36/6/article-p1061.xml, Access in: $15 / 07 / 19$

DONG, S.; CHENG, L.; SCAGEL, C. F.; FUCHIGAMI, L. H., 2002. Nitrogen absorption, translocation and distribution from urea applied in autumn to leaves of young potted apple (Malus domestica) trees. Tree Physiology, Victoria, v. 22, p. 1305-1310. Available at: https://academic.oup.com/treephys/article/22/18/1305/1623867?searchresult=1, Access in: 20/06/19

FERNÁNDEZ, V.; BROWN, P. H., 2013. From plant surface to plant metabolism: the uncertain fate of foliar-applied nutrients. Frontiers in Plant Science, Lausanne, v. 4, p. 1-5. Available at: https://www.ncbi.nlm.nih.gov/pmc/articles/PMC3728483/, Access in: 23/08/19

FREITAS, D. S.; RODAK, B. W.; A. R. REIS; F. B. REIS; T. S. C; J. SCHULZE; M. A. C. CARNEIRO; L. R. G. GUILHERME., 2018. Hidden nickel deficiency? Nickel fertilization via soil improves nitrogen metabolism and grain yield in soybean genotypes, Frontiers in Plant Science, Lausanne, v. 9, p. 1-16. Available at: https://www.frontiersin.org/articles/10.3389/fpls.2018.00614/full, Access in: 02/08/19

GERENDAS, J.; ZHU, Z.; SATTELMACHER, B., 1998. Influence of N and Ni supply on nitrogen metabolism and urease activity in Rice (Oriza sativa L.). Journal of Experimental Botany, Oxford, v. 49, n. 326, p. 1545-1554. Available at: https://academic.oup.com/jxb/article/49/326/1545/532154, Access in: 15/06/19

HAYTOVA, D., 2013. A review of foliar fertilization of some vegetables crops. Annual Review \& Research in Biology, New Delhi, v. 3, n. 4, p. 455-465. Available at: http://www.journalrepository.org/media/journals/ARRB_9/2013/Jun/1371528572Haytova342013ARRB3872.pdf., Access in: 02/08/19

HOSSEINI, H.; KHOSHGOFTARMANESH, A.H., 2013. The effect of foliar application of nickel in the mineral form and urea-Ni complex on fresh weight and nitrogen metabolism of lettuce. Scientia Horticulturae, Amsterdam, v. 164, p. 178-182. Available at: https://www.sciencedirect.com/science/article/pii/S0304423813004895, Access in: 15/08/19

JANJANIN, D.; KAROGLAN, M.; CUSTIC, M. H.; BUBOLA, M.; OSRECAK, M.; PALCIC, I., 2016. Response of 'Italian Riesling' leaf nitrogen status and fruit composition (Vitis vinifera L.) to foliar nitrogen fertilization. Hortscience, Alexandria, v. 51, n. 3, p. 262-267. Available at: https://journals.ashs.org/hortsci/view/journals/hortsci/51/3/article-p262.xml, Access in: $15 / 08 / 19$

KLEIN, I.; WEINBAUM, S. A., 1985. Foliar application of urea to almond and olive: leaf retention and kinetics of uptake. Journal of Plant Nutrition, New York, v. 8, p. 117-129. Available at: https://www.tandfonline.com/doi/abs/10.1080/01904168509363329, Access in: 20/07/19

KROGMEIER, M.J.; MCCARTY, G.W.; SHOGREN, D.R.; BREMNER, J.M., 1991. Effect of nickel deficiency in soybeans on the phytotoxicity of foliar-applied urea. Plant and Soil, Ames, v. $135, \quad$ n. 2, p. 283-286. Available at: https://link.springer.com/article/10.1007/BF00010917, Access in: 15/08/19

MALAVOLTA, E., 2006. Manual de nutrição mineral de plantas, São Paulo: Editora Agronômica Ceres, 638 p. 
MENDES, H. C.; FRANCO, C. M.; GALLO, J. R.; MORAES, M. V., 1961. Absorção de ureia pelas folhas de cafeeiro. Bragantia, Campinas, v. 20, p. 513-529.

MORAES, M. F.; REIS, A. R.; MORAES, L. A. C.; LAVRES-JUNIOR, J.; VIVIAN, R.; CABRAL, C. P.; MALAVOLTA, E., 2009. Effects of molybdenum, nickel, and nitrogen sources on the mineral nutrition and growth of rice plants. Communications in Soil Science and Plant Analysis, Philadelphia, v. 40, p. 3238-3251. Available at: https://www.tandfonline.com/doi/abs/10.1080/00103620903267590, Access in: 02/08/19

POLACCO, J.C.; MAZZAFERA, P.; TEZOTTO, T., 2013. Opinion - nickel and urease in plants: still many knowledge gaps. Plant Science, Shannon, v. 199-200, p. 79-90. Available at: https://www.sciencedirect.com/science/article/pii/S016894521200221X, Access in: 15/08/19

RUAN, J.; GERENDÁS, J., 2015. Absorption of foliar-applied urea- ${ }^{15} \mathrm{~N}$ and the impact of low nitrogen, potassium, magnesium and sulfur nutritional status in tea (Camellia sinensis L.) plants. Soil Science and Plant Nutrition, Oxford, v. 61, n. 4, p. 653-663. Available at: https://www.tandfonline.com/doi/full/10.1080/00380768.2015.1027134, Access in: 02/08/19

SINGH, J.; SINGH, M.; JAIN, A.; BHARDWAJ, S.; SINGH, A.; SINGH, D. K.; BHUSHAN, B.; DUBEY, S. K., 2013. An introduction of plant nutrients and foliar fertilization: a review. In: Precision farming: a new approach, New Delhi: Daya Publishing Company, p. 252-320.

STATSOFT, INC., 2007. Statistica: data analysis software system, version 8.

STIEGLER, J. C.; RICHARDSON, M. D.; KARCHER, D. E., 2011. Foliar nitrogen uptake following urea application to putting green turfgrass species. Crop Science, Fayetteville, v. 51, p. 1253-1260. Available at: https://dl.sciencesocieties.org/publications/cs/abstracts/51/3/1253, Access in: 18/07/19

TRIVELIN, P. C. O.; CARVALHO, J. G.; SILVA, A.Q.; PRIMAVESI, A. C. P. A.; CAMACHO, E.; EIMORI, I. E.; GUILHERME, M. R., 1988. Foliar fertilization of sugarcane (Saccharum spp.): absorption and translocation of ${ }^{15} \mathrm{~N}$-labeled. Energia Nuclear na Agricultura, Piracicaba, v. 9, n. 2, p. 52-65.

WALKER, C. D.; GRAHAM, R. D.; MADISON, J. T.; CARY, E. E.; WELCH, R. M., 1985. Effects of Ni deficiency on some nitrogen metabolites in cowpeas (Vigna unguiculata L. Walp). Plant Physiology, Rockville, v. 79, p. 474-479. Available at: http://www.plantphysiol.org/content/79/2/474, 15/08/19

Received in: August, 19, 2019

Accepted in: December, 12, 2019 